\title{
Characterizing third-party logistics setups in the context of construction
}

\author{
Anna Fredriksson, Mats Janné and Martin Rudberg \\ Department of Science and Technology, Linköping University, \\ Norrköping, Sweden
}

\begin{abstract}
Purpose - The use of third-party logistics (TPL) setups in construction has increased but is still a new phenomenon. The purpose was to increase understanding of how structural and management dimensions are related in CLSs by describing how CTPL setups are used.

Design/methodology/approach - Ten dimensions to describe and structure CLSs were identified from the literature and used to structure a cross-case analysis of 13 Swedish CLSs.

Findings - The main findings are: (1) there are three typical initiators of CLSs: municipalities, developers and contractors; (2) CLSs are drivers for service differentiation and modularization among TPL providers as construction specific services are required; (3) CLSs play a new role in construction by coordinating logistics activities between the construction project and the vicinity of the site.

Research limitations/implications - The study is based on 13 cases in the Swedish construction context. Additional studies of CLSs in other countries are needed.

Practical implications - The ten dimensions can be used as a guide in designing a CLS and in determining the order of design decisions. The identification and structuring of CTPL services also exemplify the variety of service offerings.

Originality/value - This is one of the first cross-case analyses of CLSs enabling the characterization of CTPL setups. This study identifies how different services included in the setup relate to the roles of SCM and logistics in construction.
\end{abstract}

Keywords Third-party logistics, Construction, Multiple case study

Paper type Case study

\section{Introduction}

According to Mckinsey and Company (2017), construction accounts for $13 \%$ of gross domestic product (GDP) globally. As much as $60-80 \%$ of the gross work involves purchased materials and services (Scholman, 1997), and logistics costs account for approximately $40 \%$ of the project cost (Jang et al., 2003). The construction industry has suffered from low productivity compared to other industries (Mckinsey and Company, 2017), and Josephson and Saukkoriipi (2007) reported that Swedish construction workers

\footnotetext{
(C) Anna Fredriksson, Mats Janné and Martin Rudberg. Published by Emerald Publishing Limited. This article is published under the Creative Commons Attribution (CC BY 4.0) licence. Anyone may reproduce, distribute, translate and create derivative works of this article (for both commercial and noncommercial purposes), subject to full attribution to the original publication and authors. The full terms of this licence may be seen at http://creativecommons.org/licences/by/4.0/legalcode

The authors would like to extend their gratitude to all the company, regional and municipal representatives that have participated in this study. Furthermore, we would like to thank the anonymous reviewers and the editor for their thorough work in reviewing the article; your work has increased the quality of the article substantially.

The research presented in this article has been financed by JPI Urban Europe/Sweden's Innovation Agency VINNOVA under Grant 2018-02499; the Development Fund of the Swedish Construction Industry, SBUF, under Grant 13605; and the L E Lundberg foundation for Research and Education.
}

\section{Third-party logistics setups in consruction}

Received 5 March 2019 Revised 23 August 2019 14 January 2020 10 May 2020

18 September 2020

15 December 2020

11 January 2021 Accepted 14 January 2021

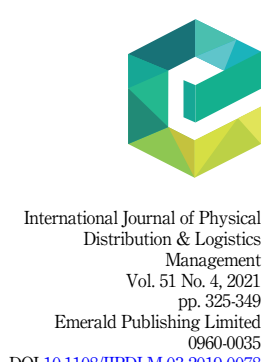


IJPDLM 51,4 spend on average over $50 \%$ of their time waiting and handling materials. Reports from the UK indicate a similar situation (Department for Business Innovation and Skills, 2013). One of the main reasons for this is the lack of proper logistics management. Several researchers have highlighted the potential for improved construction industry performance through improved supply chain management (SCM) and logistics management (Vrijhoef and Koskela, 2000; Sundquist et al., 2018). However, difficulties in achieving potential improvements have also been reported (Dubois and Gadde, 2000; Cheng et al., 2010).

To achieve the benefits of SCM and logistics management in any industry, the service network on which the industry depends must be transformed (Gebauer et al., 2013). In construction, this transformation is facilitated by third-party logistics (TPL) providers establishing themselves in construction supply chains by bundling services specifically aimed at construction projects. Construction industry representatives refer to these as construction logistics setups (CLSs). However, to provide these CLSs, the TPL industry and the logistics service research area must acknowledge the dynamic and multifaceted nature of logistics services (Halldórsson and Vural, 2019). TPL companies must adapt their service offerings as the construction industry poses several unique challenges. One example is the physically big and immobile products that are produced at the site of use. This makes the typical construction supply chain convergent (Jang et al., 2003) as all resources, labor and materials must be delivered to the construction site (Ying et al., 2018). These temporary organizations require the establishment of temporary supply chains (Vrijhoef and Koskela, 2000). The construction supply chain structure in most cases is fragmented, consisting of many small firms acting as subcontractors (Dubois and Gadde, 2002a). Subcontractors have grown accustomed to managing their own logistics (Dubois et al., 2019) owing to the lack of logistics coordination amongst main contractors (Ying et al., 2018), which creates resistance to adopting the services of CLSs (Janné and Fredriksson, 2019).

This research tackles two challenges: (1) the construction industry must improve its logistics management and (2) the TPL industry and the logistics service research area must identify how to design and develop CLSs. Input from established fields and new societal and industrial challenges should be considered in theory development Halldórsson et al. (2015). SCM and logistics is an applied field constantly challenged by theoretical developments in related disciplines and emerging societal challenges (Halldórsson et al., 2015). However, the construction logistics research stream has not benefitted from the existing and ongoing research on TPL services, and TPL research has not been challenged by the contextual issues of construction. Only a few case studies of construction TPL (CTPL) exist. These include Lindén and Josephson (2013), Lundesjö (2015), Robbins (2015), Ekeskär and Rudberg (2016), Sundquist et al. (2018), Janné and Fredriksson (2019), Dubois et al. (2019), and Janné and Rudberg (2020). These studies have explored the introduction of CLSs through single case studies and treated CTPL as a new phenomenon, focusing on reporting barriers and impacts from singular projects. The majority of the studies have concluded that contractors lack understanding of why CLSs are introduced (Sundquist et al., 2018) and how they aid in increasing construction productivity (Ekeskär and Rudberg, 2016) and decrease the potential impact of CLSs. According to Janné and Rudberg (2020), one reason is that the initiators have problems communicating the structural and managerial implications of a CLS, and consequently, how the end users should integrate the CLS into their supply chains to benefit from them. The result of this is that CLSs do not achieve their intended coordination effects.

There is a need to extend the research on CTPL practice and to provide insights for further development of theory and practice through descriptive and explanatory studies. The 
purpose of this study is to increase understanding of how structural and management dimensions are related in CLSs by describing how CTPL setups are used. Halldórsson et al. (2015) have suggested that the theorization of SCM can be approached from three dimensions; 1. creating knowledge at intersections by studying a phenomenon in relation to the supply chain, 2. creating knowledge in both directions by iteratively testing theoretical insights and empirical findings against one another, 3. creating knowledge from an application to actionable knowledge, e.g. by explaining the studied phenomena from a theoretical approach. This study approaches the research on CTPL from the last two dimensions through a crosscase analysis of 13 CLSs in Sweden. The research was guided by the following research questions:

RQ1. What structural and management dimensions are suitable for classifying CLSs?

$R Q 2$. What characterizes different CLSs based on the structural and management dimensions identified?

The paper is structured as follows: A theoretical background to TPL and CTPL is presented first. An analytical framework for CLS dimensions is developed after this (Table 1). Next, the methodology is explained, including the background to the cases. The results follow, including empirical data and the cross-case analysis. The paper ends with a discussion and conclusions.

\section{Construction logistics and construction TPL}

Ghanem et al. (2018) characterized construction logistics into two primary functions: the management of logistics activities on construction sites and the transport of resources and materials to and from construction sites. Construction logistics includes a wide array of services; some are unique to the industry, such as managing hoists and cranes and on-site storage and handling (Lundesjö, 2015). Due to the temporary nature of construction projects and that each project takes place at a new location (Lundesjö, 2015), it becomes necessary to plan for logistics as part of project planning. Therefore, we define a construction logistics setup (CLS) as a governance structure for a construction project that has been agreed on to control, manage, and follow up the flow of materials, waste, machinery and personnel to, from and on the construction site.

The TPL concept has developed as firms have come to outsource parts, or all, of their logistics operations to a specialized firm, i.e., a TPL service provider (Selviaridis and Spring, 2007). Outsourcing is the norm in the construction industry as the construction process is typically carried out within temporary organizations and supply chains (Vrijhoef and Koskela, 2000). Outsourcing logistics activities is not farfetched. The outsourcing of logistics activities is justified from the perspective of the main contractors to increase a project's relative value-adding time (Ying et al., 2018) and to achieve the same type of benefits as seen in other industries, e.g. improved service levels; end-customer satisfaction; improved access to and application of, technology; reduced capital investment in facilities, equipment and manpower; increased flexibility and productivity; improved employee morale and access to wider markets and new competencies (Marasco, 2008). The construction industry's lack of productivity due to shortcomings in logistics management was highlighted during the 1990's and early 2000's, (Josephson and Saukkoriipi, 2007). One of the reasons was that logistics was not seen as a value-creating activity. This led to the emergence of research efforts in construction logistics and SCM (Vrijhoef and Koskela, 2000). Vrijhoef and Koskela (2000) identified four roles of SCM and logistics in construction, which Ekeskär and Rudberg (2016) expanded into five: (1) a focus on clarifying the interface between the supply chain and site activities, (2) a focus on improving the supply chain, (3) a
Third-party logistics setups in consruction

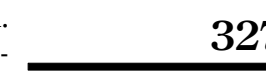


IJPDLM 51,4

focus on improving logistics at the construction site, (4) the transfer of activities from a site to the supply chain and (5) managing the site and the supply chain as an integrated domain to accomplish integrated supply chain planning and clear roles and responsibilities among actors (Ekeskär and Rudberg, 2016). There has been increased interest in utilizing CLSs and CTPL to achieve these five roles.

\section{8}

\section{Analytical framework}

According to Halldórsson et al. (2015), key aspects of SCM include the design of a supply chain network structure and the management of such a structure through interorganizational relationships. Research on traditional TPL setups is reviewed below based on the division between structure and management, and existing studies from the construction context are added to show possible adaptions that fit with the demands of the construction industry. This results in the identification of dimensions with which to characterize CLSs (see Table 1).

\footnotetext{
Structural dimension Content

1 No. of services included TPL setups are composed of either simple or complex service bundles Berglund et al. (1999), Selviaridis and Spring (2007), Kowalkowski et al. (2017), Scarsi and Spinelli (2017), Halldórsson and Altuntaş Vural (2019)

2 Level of customization Standard, partly customized, fully customized Skjøtt-Larsen (2000), Hertz and Alfredsson (2003), Brax et al. (2017), Kowalkowski et al. (2017), Scarsi and Spinelli (2017), Halldórsson and Altuntaş Vural (2019)

3 Type of services included

Asset-based, non-asset-based or value-creating Berglund et al. (1999), Voordijk (2000), Stefansson (2006), Josephson and Saukkoriipi (2007), Selviaridis and Spring (2007), Segerstedt and Olofsson (2010), Hosie et al. (2012), Lindén and Josephson (2013), Saglietto (2013), Shaharudin et al. (2014), Lundesjö (2015), Ekeskär and Rudberg (2016), Ghanem et al., 2018; Sundquist et al. (2018), Heaslip and Kovács, 2019)

4 Actors involved in the setup

5 Location in relation to project

Developer, main contractor, subcontractor, suppliers, retailers, building merchants, transport provider (Lundesjö, 2015; Ekeskär and Rudberg, 2016; Sundquist et al., 2018; Dubois et al., 2019; Janné and Fredriksson, 2019)
Close to site or far away Dubois and Gadde, (2000), Lundesjö (2015), Ekeskär and Rudberg (2016)
}

Management dimensions

Table 1. Structural and management dimensions to categorize CLSs
6 Purposes of the setup

The municipality must coordinate construction traffic with the rest of the traffic in the city Lundesjö (2015), Robbins (2015), Dubois et al. (2019), the developer must reduce disturbances to surrounding buildings and tenants Ekeskär and Rudberg (2016), Dubois et al. (2019), and the main contractor must manage a network of multiple supply chains to the construction site Vrijhoef and Koskela (2000), Lundesjö (2015), Ghanem et al. (2018), Dubois et al. (2019)

7 Business relationships Arm's length (adversarial), contractual, understanding, mutual benefit, rules of use Berglund et al. (1999), Skjøtt-Larsen et al. (2006), Selviaridis and Spring (2007), Marasco (2008), Chakkol et al. (2018), Janné and Fredriksson (2019) Short-term (per project), medium-term (set of projects/program), long-term (many years) Skjøtt-Larsen et al. (2006), Selviaridis and Spring (2007)

8 Time horizon

9 Joint investments

10 Performance evaluation (2000)

Costs, services, "smoothness of operations," delivery performance, flexibility, governance adherence, etc. Selviaridis and Norrman (2015), Ying et al. (2018) 
Structure-related dimensions of TPL and CTPL

Supply chain network structure refers to the actors who are members of the supply chain, the structural dimensions of the network and the activities each actor performs, i.e. the process links across the supply chain (Lambert and Cooper, 2000). Outsourcing entails a transfer of activities, resources and decision-making from internal to external control and thereby a change in who executes an activity (Fredriksson, 2011). For this reason, supply chain structures are created by the ways logistics are outsourced. Marasco (2008) argues that the TPL provider acts as an intermediary between two supply chain companies. As outsourcing is the norm in the construction industry (Vrijhoef and Koskela, 2000), the construction supply chain already includes a large number of actors, e.g. developers, main contractors, subcontractors, suppliers, retailers, building merchants and transport providers (Janné and Fredriksson, 2019). The large number of actors together with the introduction of a CLS requires a clarification of what activities are to be performed by which construction actor or to be part of the services by a CTPL provider (Sundquist et al., 2018). Therefore, which actors (Janné and Fredriksson, 2019) and which services are included (Heaslip and Kovács, 2019) form the base of the CTPL structure. As service is a multifaceted construct, the service concept is discussed below.

The complexity of the supply chain structure in a TPL setup depends on if the setup includes simple or complex service bundles (Halldórsson and Vural, 2019). The more services included, the higher the complexity of the service offering (Scarsi and Spinelli, 2017). Thus, Kowalkowski et al. (2017) underline the number of services as a good way to identify the size and complexity of a TPL setup. However, a major challenge for TPL providers is to adapt to individual customerservice demands while balancing systems and businesses to coordinate multiple customers (Hertz and Alfredsson, 2003). Most construction projects require a new CLS, and there is ongoing service differentiation within the TPL industry that leads to a growth in the number of possible services to include in the setup (Scarsi and Spinelli, 2017). The TPL provider can gain the specific logistics capabilities needed for a certain customer or industry segment through service differentiation (Halldórsson and Vural, 2019), enabling the development of niche service offerings targeting industry- or product-specific segments (Scarsi and Spinelli, 2017). Servitization research shows that service offerings are shifting from complex to standardized sets of services, creating modularity in service offerings (Kowalkowski et al., 2017). According to Brax et al. (2017), this modularity can be utilized as a means to create customized service offerings. Customization is thus a dimension that affects the CLS structure.

Central to the CLS concept is which services are available as the logistics roles a CLS can fulfill depends on the services included. These are dependent on the assets or knowledge resources the service provider possesses (Stefansson, 2006). Heaslip and Kovács (2019) describe service development in three steps: (1) asset-based services focused on supporting the product, (2) nonasset-based services focused on supporting the customer and (3) valuecreating services that provide a competitive advantage by supporting both product and customer. Asset-based providers own physical assets (trucks, warehouses, etc.) and focus on the management and execution of transport and warehouse-related activities, such as inventory management (e.g. materials handling, repackaging), value-adding activities (e.g. secondary assembly, installation of products) (Selviaridis and Spring, 2007) and return logistics flows (Shaharudin et al., 2014). Nonasset-based providers, in contrast, rely on human expertise and information systems and include management-oriented services, subcontracting physical distribution activities to asset-based companies (e.g. tracking and tracing, distribution planning) as well as designing and reengineering the supply chain (Selviaridis and Spring, 2007). Value-creating providers have developed since the mid 2000's as the concept of fourth-party logistics (4PL), acting as coordinators or orchestrators of supply chains (Saglietto, 2013). 4PL stems from digitalization, and its opportunities for services focus on the planning and coordination of supply chains (Saglietto, 2013). The concept of fifth-party logistics (5PL) was introduced more recently; the 5PL provider designs
Third-party logistics setups in consruction 
IJPDLM 51,4 and manages the entire supply chain at the strategic level, utilizing innovative logistics concepts (Hosie et al., 2012).

One of the main features of a CLS operator, i.e. a CTPL provider, is to provide valuecreating services (including planning systems) and acting as a systems coordinator (Segerstedt and Olofsson, 2010). The physical structure of the off-site part of CLSs is organized around either an asset-based terminal setup or a nonasset-based checkpoint (Ghanem et al., 2018). The purpose of terminals is to reduce unnecessary freight movements through coordination and consolidation (Lundesjö, 2015). Checkpoints secure just-in-time (JIT) deliveries through time-slot bookings that specify materials and volumes arriving, the type of delivery vehicle and whether specific handling equipment is needed (Voordijk, 2000). Nonasset-based services are usually offered to manage on-site logistics, such as loading and unloading zones (Lundesjö, 2015), logistics-based site plans (Josephson and Saukkoriipi, 2007), materials handling manpower (Lindén and Josephson, 2013), waste management (Lundesjö, 2015) and site coordination (Sundquist et al., 2018).

Since each construction project has a new location (Dubois and Gadde, 2000), the location of off-site services in relation to the construction site is an issue specific to construction (Lundesjö, 2015) and was included as a dimension for analysis. The CTPL provider enters the construction site with services such as on-site materials handling as these activities were previously performed by contractors. Activities previously performed by a contractor, such as bundling material or order planning, can be "lifted" out from the construction site and performed by the CTPL provider in another location. Typical locations to consider are terminals or parking lots close to the construction site or existing warehouses or parking lots farther away with a checkpoint close to the construction site (Ekeskär and Rudberg, 2016).

The structural dimensions by which a CLS should be analyzed are the actors involved and the number, type, customization level and location of services (Table 1).

\section{Management-related dimensions of TPL and CTPL}

Lambert and Cooper (2000) describe the management dimension of SCM as the level of integration and management for each process link within a structure, indicating that a structure is developed before management. Christopher (2011) describes that the integration of material flows, information flows, and monetary flows within and between companies is the integration of supply chains. According to Fredriksson and Jonsson (2009), the integration level can be analyzed by viewing governance structure and management level as the business relationship and the operative dependencies between the actors. The operative dependencies depends on what activities have been outsourced and thereby what services are part of the CLS (Fredriksson and Jonsson, 2009). Thus, these activities link structural dimensions to management dimensions.

The governance structure dictates the contractual agreement between the parties. The Nordic TPL research stream argue that traditional TPL relationships are characterized by longterm contracts with a minimum 2-3 years' time horizon (Skjøtt-Larsen et al., 2006). Selviaridis and Spring (2007) highlight that the relationship between client and TPL provider must be contractually established over a longer time period for the relationship to be considered a TPL arrangement. Another important aspect of the governance structure and thereby part of the contractual agreement is whether or not there are any joint investments in the TPL arrangement that need to be jointly managed (Skjøtt-Larsen, 2000). Finally, performance measurement is an important dimension to analyze in all TPL relationships, e.g. to know if the operative dependencies are managed in a satisfying way (Ying et al., 2018), what services are to be seen as success factors or service qualifiers (Atkinson, 1999) and if the governance structure balances risk and rewards between customer and service provider (Selviaridis and Norrman, 2015). 
According to Berglund et al. (1999), the business relationship aspect of TPL arrangements distinguishes them from regular sourcing of transportation and/or warehousing. The reason behind the decision to use a TPL provider in a traditional TPL setup affects the relationship between the shipper and the provider, with cost reasons having a tendency to lead to arm's length relationships and knowledge-seeking reasons to closer, partner-like, relationships (Marasco, 2008). This business relationship dimension is not as straightforward in CLSs because of the many actors involved, and the different actors can initiate the use of CLSs. As discussed by Janné and Fredriksson (2019), for instance, a CLS can be initiated by one party, operated and controlled by a second party, partially paid for by a third and utilized and paid for by a fourth. This adds a complexity to the business relationships that is not usually found in traditional TPL arrangements between a provider and customer (Marasco, 2008). What forms the business relationships of CLSs depends on who the initiating actor is and their purpose of introducing the CLS. CLSs seem to emerge from three different initiators: a contractor (Dubois et al., 2019), a developer (Ekeskär and Rudberg, 2016) or a municipality (Lundesjö, 2015). These initiators have different purposes with the CLS, and thereby the purpose of the CLS is an important dimension. Municipalities, for instance, involve TPL providers and initiate CLSs as part of the city logistics research realm (Lundesjö, 2015). This research stream takes the perspective of the municipality and its need to coordinate construction traffic with other traffic in the city. Many large construction projects in urban areas need CLSs to manage these issues (Robbins, 2015), and urban planning has started introducing different CLSs similar to city logistics initiatives (Dubois et al., 2019). This also means that business relationships must be managed in a different way as CLSs include many actors, indicating that not all CLSs can be seen as traditional TPL relationships. Chakkol et al. (2018) point out that the business relationships in these complex settings must be managed from a relationship perspective aimed at mutual benefits. However, these relationships also must be stipulated in contract form (Selviaridis and Norrman, 2015)

The management dimensions that should be used in a CLS analysis are: time horizon, joint investments, the performance measurement, business relationships and purpose.

\section{Methodology}

\section{Research process and case selection}

This research has followed an abductive approach (Dubois and Gadde, 2002b). The research process started in 2014 based on a request from main contractors and the few existing CTPL service providers to measure the impact of the setups. This raised the question of which dimensions to use to analyze a CLS. Construction logistics research was examined first, which lead to the identification of the dimensions: actors involved in the setup, type of services included, level of customization and location in relation to the project. Next, the TPL research was examined, which added the dimensions: number of services, business relationships, time horizon, joint investments and performance evaluation. A first version of Table 1 emerged. When this framework was applied, it was found necessary to clarify which actor initiated a setup. This steered the focus to city logistics research, and the dimension purposes of the setup was added. From the cases and the development of CLSs, we also detected modularization in relation to the dimension level of customization, and the service modularization literature was examined. Finally, descriptions of asset-based, non-asset-based and value-creating services were added to be able to classify the type of services identified in the cases. These were based on findings from the review process. The abductive nature of this study also helps to increase the generalizability of the results (Yin, 2014).

The unit of analysis in this paper is the CLS. The natural choice was a multiple case study since a comparison of a few specific variables informed the research questions (Dubois and Gadde, 2002b). The CLSs investigated were identified by combining knowledge of their
Third-party logistics setups in consruction 
IJPDLM 51,4 existence from ongoing research projects and a snowballing technique; interviews regarding one solution provided information about other setups to investigate. The cases were chosen based on the following criteria: (1) a TPL setup involving at least two actors (TPL provider and customer), (2) dedicated to construction customers only and (3) implemented in Sweden. The contextual backgrounds of the selected CLSs are presented in Table 2.

\section{2}

\begin{tabular}{|c|c|c|c|c|c|}
\hline Case & $\begin{array}{l}\text { Type of } \\
\text { construction } \\
\text { project }\end{array}$ & $\begin{array}{l}\text { Project- } \\
\text { specific } \\
\text { logistics } \\
\text { setup }\end{array}$ & $\begin{array}{l}\text { Location of construction/ } \\
\text { development project }\end{array}$ & $\begin{array}{l}\text { Scope of construction/ } \\
\text { development project }\end{array}$ & $\begin{array}{l}\text { Construction/ } \\
\text { development } \\
\text { project time-frame }\end{array}$ \\
\hline A & $\begin{array}{l}\text { Urban } \\
\text { development } \\
\text { project }\end{array}$ & Yes & $\begin{array}{l}\text { Central city location, adjacent } \\
\text { to existing housing, business } \\
\text { locations and ports }\end{array}$ & $\begin{array}{l}12,000 \text { apartments and } \\
\text { single-family houses } \\
35,000 \text { new } \\
\text { workplaces }\end{array}$ & 25 years \\
\hline B & $\begin{array}{l}\text { Shopping mall, } \\
\text { housing, } \\
\text { workplaces, and } \\
\text { hotels }\end{array}$ & Yes & $\begin{array}{l}\text { Middle of city center, } \\
\text { surrounded by shopping } \\
\text { districts, business locations } \\
\text { and cultural and historical sites }\end{array}$ & $\begin{array}{l}5 \text { buildings } \\
\text { Two squares and four } \\
\text { streets } \\
6,000 \text { new workplaces } \\
1,100 \mathrm{~m}^{2} \text { of housing } \\
2,500 \mathrm{~m}^{2} \text { of rooftop } \\
\text { landscapes }\end{array}$ & 5 years \\
\hline $\mathrm{C}$ & Office complex & No & $\begin{array}{l}\text { Urban location, adjacent to } \\
\text { existing housing blocks, a } \\
\text { large mall, office buildings, an } \\
\text { arena and a large railway node }\end{array}$ & $\begin{array}{l}3 \text { housing blocks } \\
90,000 \mathrm{~m}^{2} \text { of floor } \\
\text { space for } 4,400 \\
\text { employees and } \\
\text { temporary visitors } \\
600 \text { conference rooms } \\
\text { Large garage } \\
\text { Employee recreation } \\
\text { center }\end{array}$ & 4 years \\
\hline $\mathrm{Da}$ & $\begin{array}{l}\text { Hospital - new } \\
\text { construction }\end{array}$ & Yes & $\begin{array}{l}\text { Central location, adjacent to } \\
\text { existing housing and business } \\
\text { locations }\end{array}$ & $\begin{array}{l}4 \text { new buildings } \\
66,000 \mathrm{~m}^{2} \text { of hospital } \\
\text { area incl. specialized } \\
\text { laboratories }\end{array}$ & 7 years \\
\hline $\mathrm{Db}$ & $\begin{array}{l}\text { Hospital - } \\
\text { renovation }\end{array}$ & Yes & $\begin{array}{l}\text { Central location, adjacent to } \\
\text { existing housing and business } \\
\text { locations }\end{array}$ & $\begin{array}{l}\text { Renovation and re- } \\
\text { build of existing } \\
\text { hospital } \\
\text { All multi-bed rooms to } \\
\text { be converted into } \\
\text { single-bed rooms }\end{array}$ & 5 years \\
\hline $\mathrm{E}$ & Shopping mall & Yes & $\begin{array}{l}\text { Urban location, adjacent to } \\
\text { existing housing blocks, a } \\
\text { large mall, office buildings and } \\
\text { a large railway node }\end{array}$ & $\begin{array}{l}\text { One new building of } \\
\text { seven floors, two of } \\
\text { them underground } \\
\text { parking } \\
100,000 \mathrm{~m}^{2} \text { of } \\
\text { floorspace }\end{array}$ & 4 years \\
\hline $\mathrm{F}$ & $\begin{array}{l}\text { Urban } \\
\text { development } \\
\text { projects }\end{array}$ & No & $\begin{array}{l}\text { Urban location, adjacent to } \\
\text { existing housing, schools, } \\
\text { business locations and } \\
\text { university }\end{array}$ & $\begin{array}{l}11,500 \text { new } \\
\text { apartments and } \\
\text { single-family houses } \\
100,000+\mathrm{m}^{2} \text { of } \\
\text { university and } \\
\text { workplace space }\end{array}$ & 9 years \\
\hline $\mathrm{G}$ & $\begin{array}{l}\text { Urban } \\
\text { development } \\
\text { project }\end{array}$ & Yes & $\begin{array}{l}\text { Urban location, adjacent to } \\
\text { existing housing, schools, } \\
\text { business locations and } \\
\text { university }\end{array}$ & $\begin{array}{l}1,000 \text { new apartments } \\
\text { and single-family } \\
\text { houses }\end{array}$ & 4 years \\
\hline
\end{tabular}

Summary of contextual university 


\begin{tabular}{|c|c|c|c|c|c|c|}
\hline Case & $\begin{array}{l}\text { Type of } \\
\text { construction } \\
\text { project }\end{array}$ & $\begin{array}{l}\text { Project- } \\
\text { specific } \\
\text { logistics } \\
\text { setup }\end{array}$ & $\begin{array}{l}\text { Location of construction/ } \\
\text { development project }\end{array}$ & $\begin{array}{l}\text { Scope of construction/ } \\
\text { development project }\end{array}$ & $\begin{array}{l}\text { Construction/ } \\
\text { development } \\
\text { project time-frame }\end{array}$ & $\begin{array}{l}\text { logistics setups } \\
\text { in consruction }\end{array}$ \\
\hline $\mathrm{H}$ & $\begin{array}{l}\text { Urban } \\
\text { development } \\
\text { project }\end{array}$ & Yes & $\begin{array}{l}\text { Urban location, adjacent to } \\
\text { existing housing, schools, city } \\
\text { center and business locations }\end{array}$ & $\begin{array}{l}750 \text { new apartments } \\
75,000 \mathrm{~m}^{2} \text { of } \\
\text { workplace space }\end{array}$ & 5 years & 333 \\
\hline I & $\begin{array}{l}\text { Primarily } \\
\text { residential and } \\
\text { office building } \\
\text { projects }\end{array}$ & No & $\begin{array}{l}\text { Approximately } 30 \text { fixed nodes } \\
\text { in the forwarder's distribution } \\
\text { network }\end{array}$ & $\begin{array}{l}\text { Offered as a possible } \\
\text { solution to all project } \\
\text { sizes above } 2.5 \text { million } \\
\text { Euros }\end{array}$ & $\begin{array}{l}\text { Long-term } \\
\text { relationship, short- } \\
\text { term for individual } \\
\text { projects }\end{array}$ & 000 \\
\hline $\mathrm{J}$ & $\begin{array}{l}\text { Shopping mall and } \\
\text { housing }\end{array}$ & Yes & $\begin{array}{l}\text { Urban location, adjacent to } \\
\text { existing housing, schools, city } \\
\text { center, business locations and } \\
\text { nature areas }\end{array}$ & $\begin{array}{l}200 \text { new apartments } \\
2,600 \mathrm{~m}^{2} \text { of office } \\
\text { space } \\
16,500 \mathrm{~m}^{2} \text { of shopping } \\
\text { space } \\
11,500 \mathrm{~m}^{2} \text { of garage } \\
\text { space }\end{array}$ & 5 years & \\
\hline K & $\begin{array}{l}\text { Hospital - } \\
\text { renovation }\end{array}$ & Yes & $\begin{array}{l}\text { Central location, adjacent to } \\
\text { existing housing and business } \\
\text { locations }\end{array}$ & $\begin{array}{l}45,000 \mathrm{~m}^{2} \text { of new } \\
\text { hospital area, } 74,000 \\
\mathrm{~m}^{2} \text { of renovation }\end{array}$ & 7 years & \\
\hline $\mathrm{L}$ & $\begin{array}{l}\text { Hospital - } \\
\text { renovation and } \\
\text { new construction }\end{array}$ & Yes & $\begin{array}{l}\text { Central location, adjacent to } \\
\text { university, housing and } \\
\text { business locations }\end{array}$ & $\begin{array}{l}12,000 \mathrm{~m}^{2} \text { of new } \\
\text { hospital area } \\
19,600 \mathrm{~m}^{2} \text { of } \\
\text { renovation }\end{array}$ & 8 years & Table \\
\hline
\end{tabular}

\section{Case analysis}

The aim of the cross-case analysis was to identify commonalities and differences between the CLSs to identify the value of the dimensions that lead to a specific outcome. The cases were analyzed by searching for logical explanations for why, how and when the CLSs were used for each case (Craighead et al., 2016). The logistics services of the CLSs were contrasted with the five roles of logistics in construction presented by Ekeskär and Rudberg (2016) to identify the why. The analysis employs the grouping process suggested by Kluge (2000), aimed at discovering whether or not it is possible to find archetypal CLSs. This process led to the development of Figure 1, illustrating the possible relationships between dimensions in the design process of a CLS.

\section{Data collection}

The main sources of data collection were on-site visits, participatory observations (e.g. attending meetings), archival records (e.g. master's thesis reports, project documents) and semi-structured interviews. The multiple data collection methods used helped to ensure validity (Yin, 2014). A research guide (Yin, 2014) was developed based on the results of the literature review, before the CLSs were investigated (Appendix 1). This guide also included questions about the context of the construction projects. After each visit, interview notes were transcribed and controlled against the research guide.

\section{CLS characteristics}

Table 3 presents the empirical data from the 13 cases, structured according to the ten dimensions in Table 1. 


\section{IJPDLM \\ 51,4}

334
Table 3.

The characteristics of the studied construction logistics cases

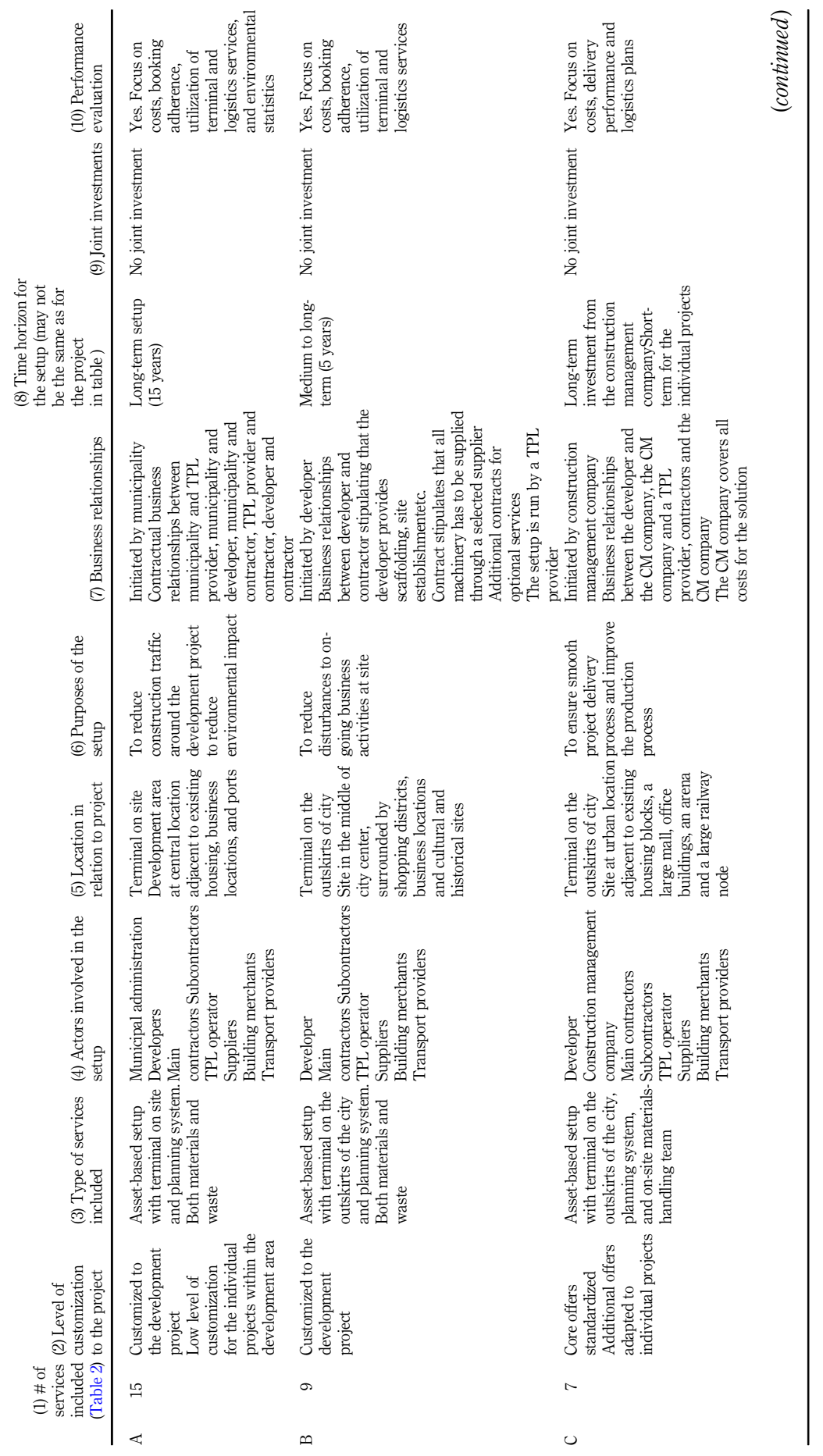




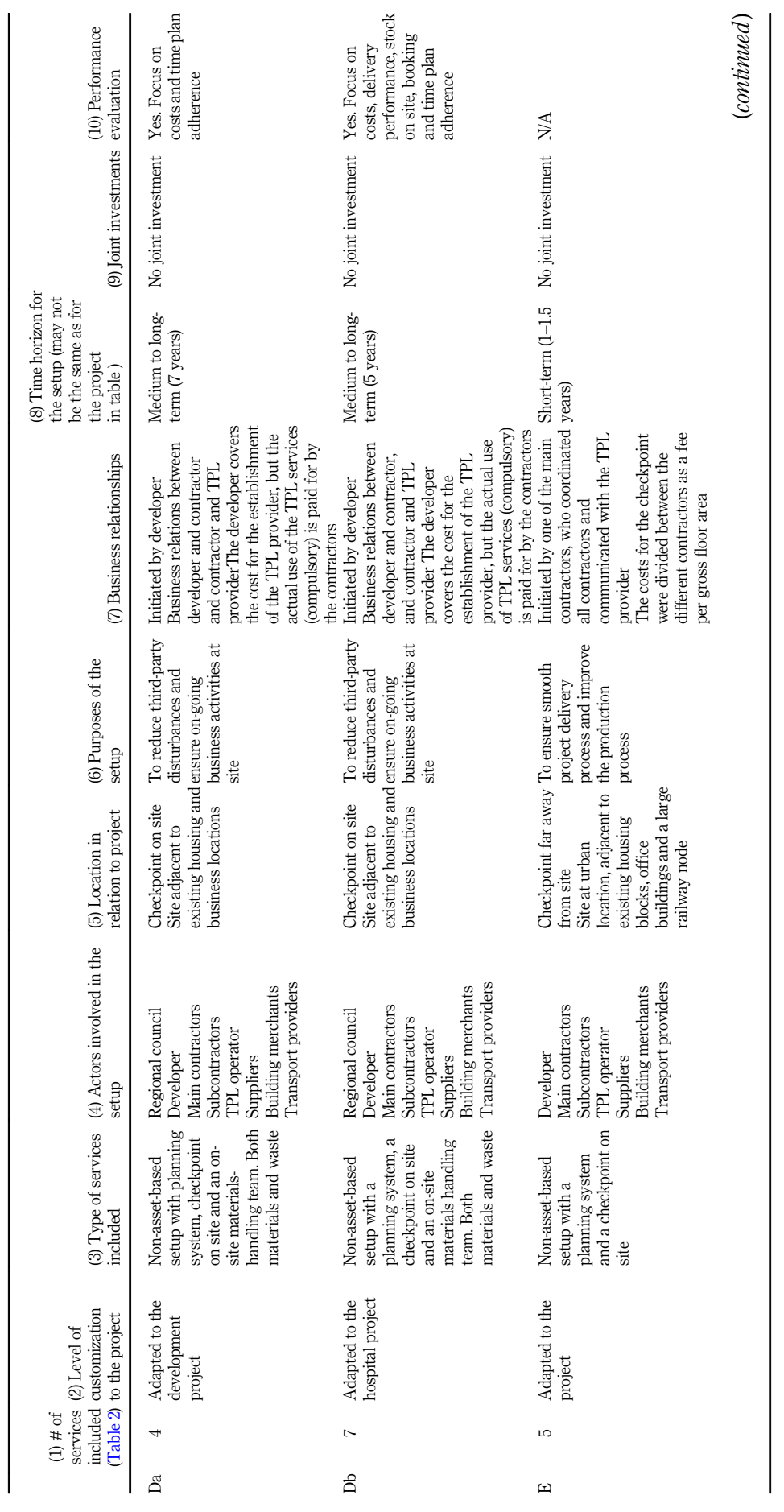

Third-party logistics setups in consruction

335

Table 3. 


\section{IJPDLM \\ 51,4}

336

$\overleftrightarrow{క}$

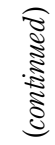

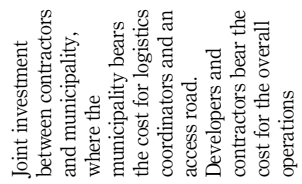

竞

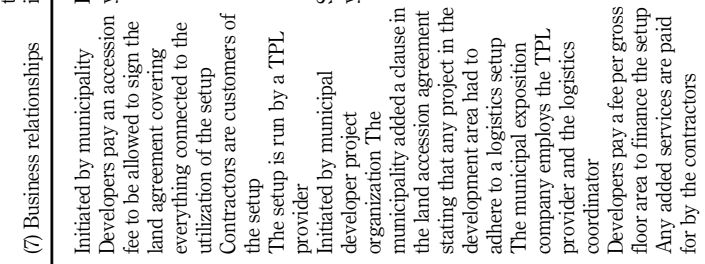

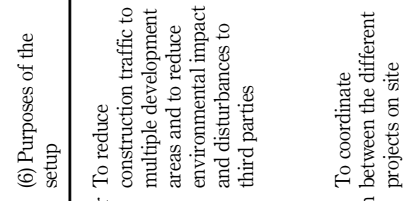

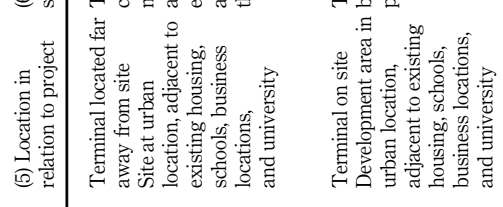

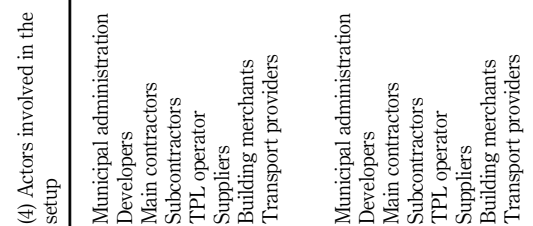

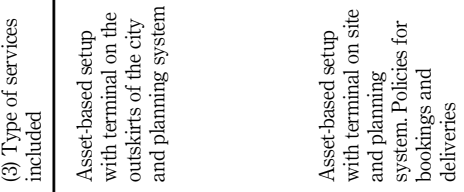

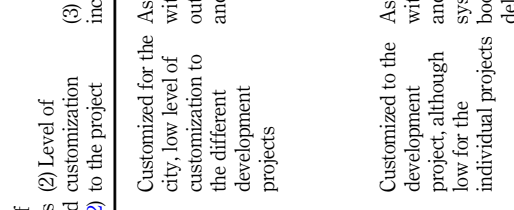

Table 3.

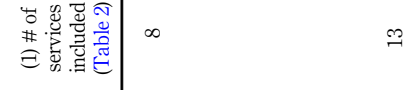

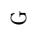




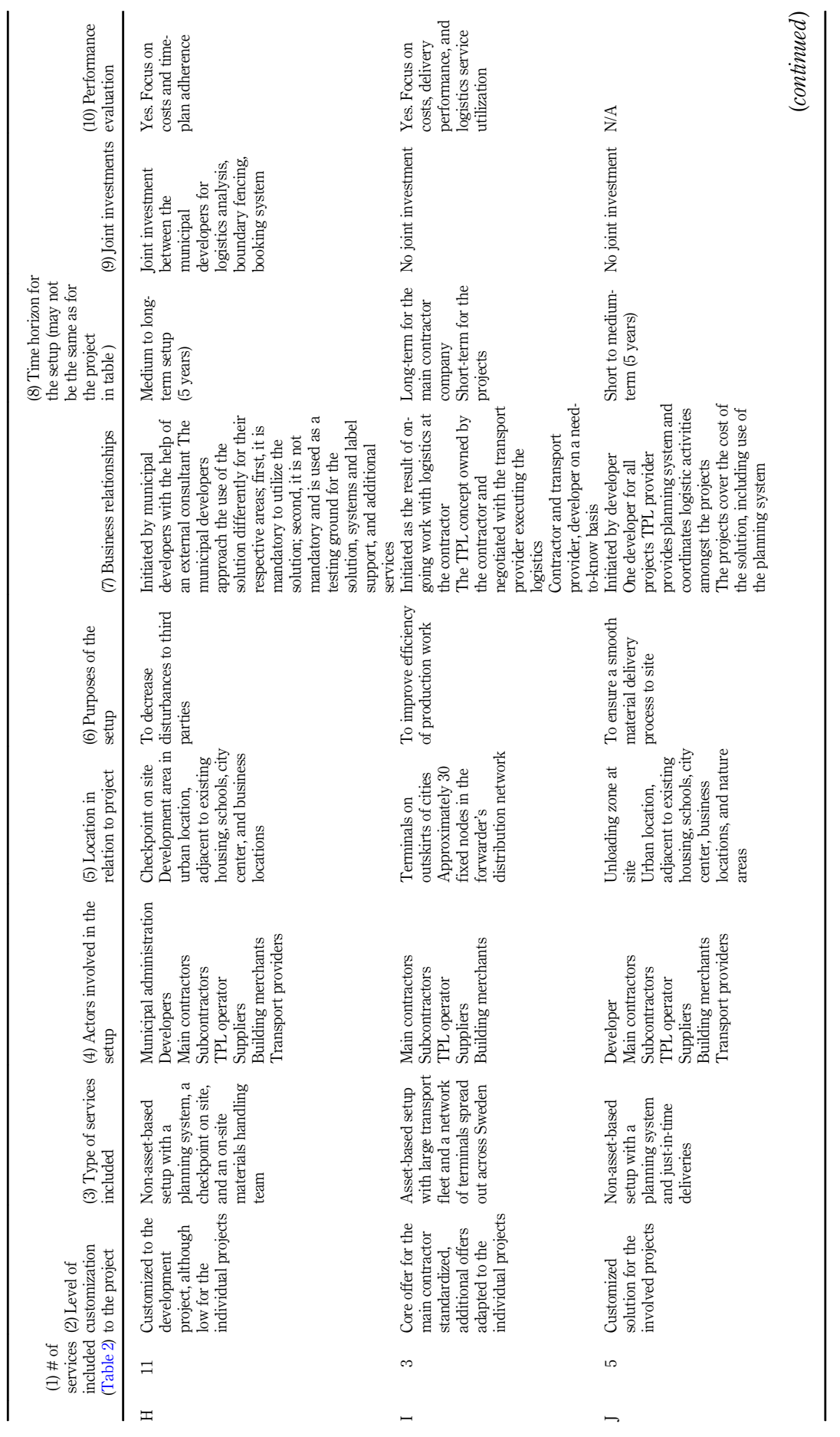

Third-party logistics setups in consruction

337

Table 3. 


\section{IJPDLM \\ 51,4}

338

Table 3.

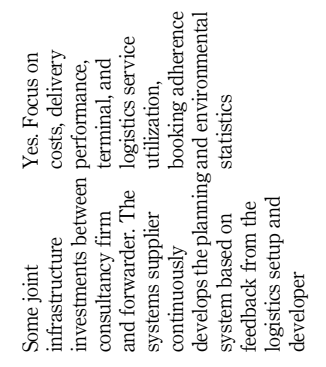

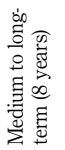

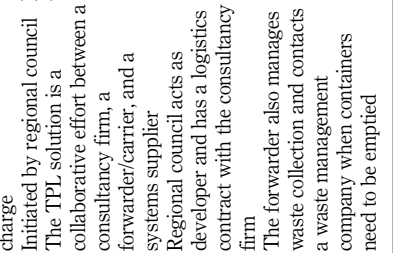

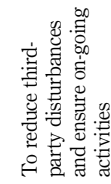
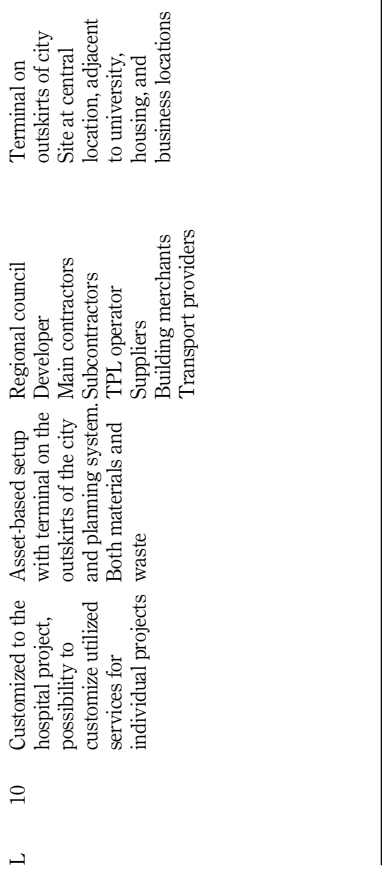
Structural dimensions

Table 4 presents the services that were offered in the 13 cases. These are structured according to Heaslip and Kovács (2019): (1) asset-based services, (2) nonasset-based services and (3) value-creating services. There was wide variety in the number of services included in the setups; $3-15$ services of the 17 different services identified. All cases included all three types of services. Cases A and G included many services (15 and 14, respectively) and were both setups serving development programs. Apart from cases C, F and I, the setups studied were customized or adapted to specific projects (Table 3). Cases $\mathrm{C}$ and I were developed by main contractors to serve a wide variety of projects, and case $\mathrm{F}$ was developed by a municipality to serve several projects within a city. All three cases were terminal-based, e.g. aiming at consolidating deliveries to the different projects.

All cases included different types of services (see Table 3). Cases A, B, C, F, G, I, and L were terminal-based, whereas cases $\mathrm{Da}, \mathrm{Db}, \mathrm{E}, \mathrm{H}$, and $\mathrm{K}$ were checkpoint-based setups, e.g. aiming at controlling deliveries with JIT-based planning. A, B, and G included both terminal and checkpoint setups. J was the only setup that did not include a checkpoint or a terminal; hence, it was a value-creating-based setup. Table 4 shows that all cases included the service "booking and planning system," which can be due to the large number of actors that each setup interacted with (Table 3).

\begin{tabular}{|c|c|c|c|c|c|c|c|c|c|c|c|c|c|c|c|}
\hline & $\mathrm{A}$ & $\mathrm{B}$ & $\mathrm{C}$ & $\mathrm{Da}$ & $\mathrm{Db}$ & $\mathrm{E}$ & $\mathrm{F}$ & $\mathrm{G}$ & $\mathrm{H}$ & $\mathrm{I}$ & $\mathrm{J}$ & $\mathrm{K}$ & $\mathrm{L}$ & Role(s) & \\
\hline \multicolumn{16}{|l|}{ Asset-based } \\
\hline $\begin{array}{l}\text { Terminal with short-term } \\
\text { storage, cross-docking, } \\
\text { kitting and transport from } \\
\text { terminal to site }\end{array}$ & $\mathrm{X}$ & $\mathrm{X}$ & $\mathrm{X}$ & & & & $\mathrm{X}$ & $\mathrm{X}$ & & $\mathrm{X}$ & & & $\mathrm{X}$ & $1-4$ & \\
\hline Boundary fencing & $\mathrm{X}$ & $\mathrm{X}$ & $\mathrm{X}$ & $\mathrm{X}$ & $\mathrm{X}$ & & $\mathrm{X}$ & $\mathrm{X}$ & $\mathrm{X}$ & & $\mathrm{X}$ & $\mathrm{X}$ & & 1 & \\
\hline Site establishment & $\mathrm{X}$ & $\mathrm{X}$ & & & & & & $\mathrm{X}$ & $\mathrm{X}$ & & & $\mathrm{X}$ & & 3 & \\
\hline Machine resources & $\mathrm{X}$ & $\mathrm{X}$ & & & & & & $\mathrm{X}$ & & & & & $\mathrm{X}$ & 3 & \\
\hline Waste management & $\mathrm{X}$ & $\mathrm{X}$ & $\mathrm{X}$ & & $\mathrm{X}$ & & & $\mathrm{X}$ & $\mathrm{X}$ & & & & $\mathrm{X}$ & 2,3 & \\
\hline \multicolumn{16}{|l|}{ Non-asset-based } \\
\hline Checkpoint with parking & $\mathrm{X}$ & $\begin{array}{l}\mathrm{X} \text { (no } \\
\text { parking) }\end{array}$ & & $\mathrm{X}$ & $\mathrm{X}$ & $\mathrm{X}$ & & $\mathrm{X}$ & $\mathrm{X}$ & & & $\mathrm{X}$ & & 1,3 & \\
\hline $\begin{array}{l}\text { On-site materials handling } \\
\text { manpower }\end{array}$ & $\mathrm{X}$ & $\mathrm{X}$ & $\mathrm{X}$ & $\mathrm{X}$ & $\mathrm{X}$ & & $\mathrm{X}$ & $\mathrm{X}$ & $\mathrm{X}$ & $\mathrm{X}$ & & & $\mathrm{X}$ & 3 & \\
\hline VMI on site & & & & & & & & & $\mathrm{X}$ & & & & & & \\
\hline Traffic piloting & $\mathrm{X}$ & & & & & $\mathrm{X}$ & & $\mathrm{X}$ & & & & & & 1,2 & \\
\hline Road maintenance & $\mathrm{X}$ & & & & & & & $\mathrm{X}$ & & & & & & 3 & \\
\hline $\begin{array}{l}\text { Surveillance and security } \\
\text { cameras }\end{array}$ & $\mathrm{X}$ & $\mathrm{X}$ & $\mathrm{X}$ & & & $\mathrm{X}$ & $\mathrm{X}$ & $\mathrm{X}$ & $\mathrm{X}$ & & & $\mathrm{X}$ & & 1 & \\
\hline \multicolumn{16}{|l|}{ Value-creating } \\
\hline $\begin{array}{l}\text { Booking and planning } \\
\text { systems }\end{array}$ & $\mathrm{X}$ & $\mathrm{X}$ & $\mathrm{X}$ & $\mathrm{X}$ & $\mathrm{X}$ & $\mathrm{X}$ & $\mathrm{X}$ & $\mathrm{X}$ & $\mathrm{X}$ & $\mathrm{X}$ & $\mathrm{X}$ & $\mathrm{X}$ & $\mathrm{X}$ & $2,3,5$ & \\
\hline $\begin{array}{l}\text { Logistics organization and } \\
\text { coordination }\end{array}$ & $\mathrm{X}$ & $\mathrm{X}$ & $\mathrm{X}$ & & & $\mathrm{X}$ & $\mathrm{X}$ & $\mathrm{X}$ & $\mathrm{X}$ & & $\mathrm{X}$ & $\mathrm{X}$ & $\mathrm{X}$ & $1,2,3,5$ & \\
\hline Site layout plans & $\mathrm{X}$ & & & & & & & $\mathrm{X}$ & & & $\mathrm{X}$ & $\mathrm{X}$ & $\mathrm{X}$ & 3 & \\
\hline Standardized labeling & & & & & & & & & $\mathrm{X}$ & & & & $\mathrm{X}$ & $2,3,5$ & \\
\hline Education & $\mathrm{X}$ & & & & $\mathrm{X}$ & & & & & & & & $\mathrm{X}$ & & \multirow{3}{*}{$\begin{array}{r}\text { Table } 4 . \\
\text { Summary of services } \\
\text { offered in the } \\
\text { different cases }\end{array}$} \\
\hline $\begin{array}{l}\text { Follow up and adherence } \\
\text { to rules }\end{array}$ & $\mathrm{X}$ & & & & $\mathrm{X}$ & & & $\mathrm{X}$ & $\mathrm{X}$ & & $\mathrm{X}$ & $\mathrm{X}$ & $\mathrm{X}$ & & \\
\hline $\begin{array}{l}\text { Total number of services } \\
\text { offered (see Table } 1 \text { ) }\end{array}$ & 15 & 9 & 7 & 4 & 7 & 5 & 8 & 14 & 11 & 3 & 5 & 8 & 10 & & \\
\hline
\end{tabular}

Third-party logistics setups in consruction 
IJPDLM 51,4

Three of the cases that utilized terminal-based setups (A, F, and $\mathrm{G})$ were connected to development programs, two (B and $\mathrm{L}$ ) were connected to geographically complex projects with many third parties nearby the sites and two ( $\mathrm{C}$ and $\mathrm{I}$ ) were initiated by main contractors to manage their logistics. The reason for using terminals is that a terminal can serve many different projects from its often more distant location. A checkpoint, at least in the studied cases, is located close to the construction site. This structure makes it hard to serve several projects.

\section{Management dimensions}

The purpose of the CLS indicates which actor initiated it (in Table 3 this is part of business relationships). The studied CLSs were initiated either by developers (B, Da, Db, G, H, J, K and $\mathrm{L}$ ), municipalities (A and F) or main contractors (C, E, and I). Cases A and F had the purpose of decreasing construction-related transports and their environmental impact. The purpose of the other setups was to reduce disturbances around the construction site $(\mathrm{B}$ and $\mathrm{H})$, facilitate material delivery to the site $(\mathrm{G}$ and $\mathrm{J}$ ) or both (Da, $\mathrm{Db}, \mathrm{K}$, and $\mathrm{L})$. The focus of the setups initiated by main contractors was to improve productivity through an efficient delivery process (C, E, and I). This indicates that different initiators have different purposes.

The business relationships were characterized by a focus on contractual issues and regulations. Contractual issues are expected in the construction industry with temporary organizations and new relationships. However, the way contracts are setup makes it unclear who the customer of the CLS is. This is exemplified by case A. Contractually, the city acted as both customer and employer of the TPL provider; the developers were customers of the city and the TPL provider as well as employers of the main contractors, and the main contractors were customers of the city and the TPL provider. The city sets the regulations for the CLS. These regulations are followed by the main contractors and followed up by the TPL provider and developers. From this, it is not clear who the actual customer of the CLS is. Of the CLSs initiated by municipalities and developers (who were not users of the services), the main contractors have a tendency not to adhere to the rules of the CLS. Hence, the service "Follow up and adherence to rules" (A, Db, G, J, K, and $\mathrm{L}$ ) is required but was not part of any of the contractor-initiated CLSs (C, E, and I).

The time horizon of the CLSs followed the timeframe of the projects they served (apart from cases C, F, and I). However, very long-term projects, such as projects A and D, have potential for new procurement of CLSs after a certain time period. Only four cases were joint investments: F, G, H and L. These were all initiated by public developers or authorities with the purpose of reducing the impact of construction traffic on third parties and the environment. Since all four were initiated a few years after other large setups by public developers (cases A, Da, and $\mathrm{Db}$ ), these setups had the opportunity to evaluate previous setups and propose joint investments to reduce the complexity of the relationships and contractual agreements.

Performance evaluation was considered in all but four cases (E, G, J, and K). The CLSs in cases $\mathrm{A}, \mathrm{B}, \mathrm{C}, \mathrm{Da}, \mathrm{Db}$ and $\mathrm{H}$ evaluated performance related to rule adherence (booking adherence, time-plan adherence, or logistics plan). Thus, there was an issue of rule enforcement alongside the performance evaluation of the utilization of CLSs and logistics services (A, B, F, I, and L). Finally, all the CLSs that evaluated performance also evaluated costs. However, classic logistics performance metrics (e.g. delivery performance) was only evaluated for in four cases (C, Db, I, and L).

\section{A theoretical framework for CLSs}

Figure 1 shows the suggested relations between the CLS dimensions based on the findings of the cross-case analysis. The relationships in Figure 1 are numbered, and the numbers are used in the analysis below to indicate the relation in focus. 

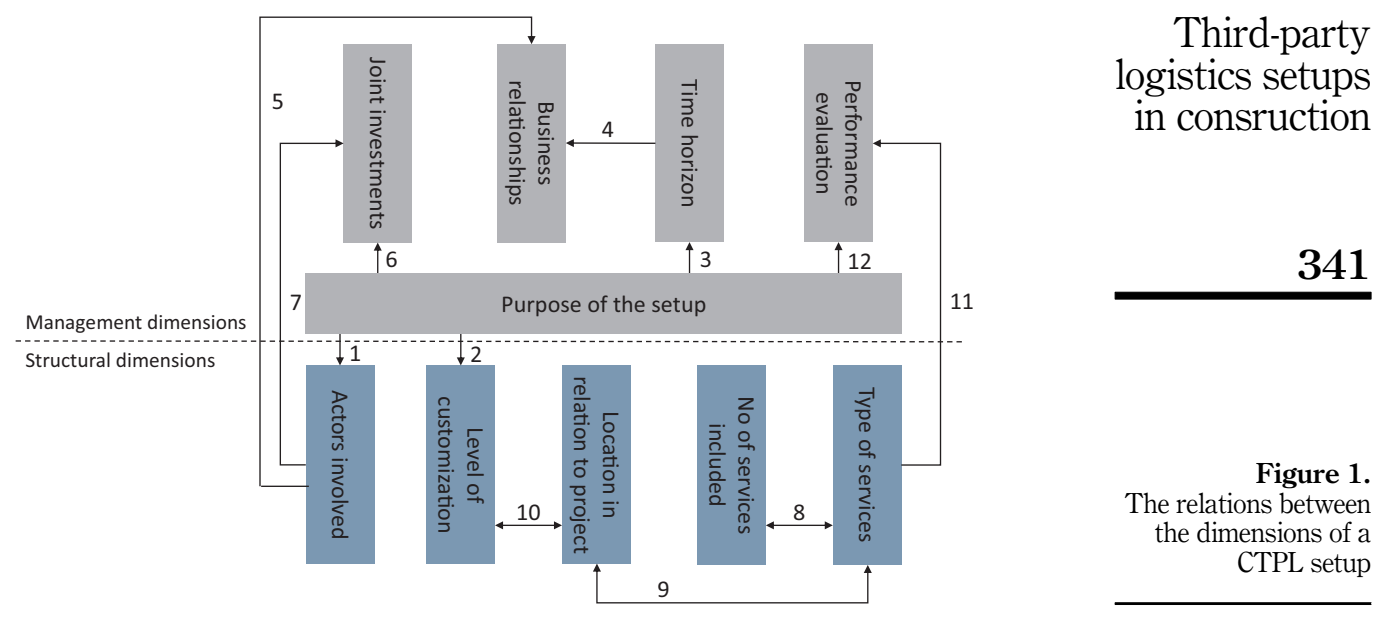

Traditional SCM research assumes that management is dependent on structure as the structure is set by which services are provided by which actor and which actors are part of the structure (Chakkol et al., 2018). However, this is not necessarily true for CLSs because of the purpose of the setup. The services included in a traditional TPL setup determine the operative dependencies between service supplier and customer (Selviaridis and Spring, 2007). In contrast, the purpose of a CTPL setup can be to reduce disturbance to surrounding areas by "forcing" contractors to be part of a CLS (Dubois et al., 2019). As noted by amongst others Janné and Fredriksson (2019), a situation can occur in construction where the initiating party dictates how the operative dependencies between service supplier and end-user are to be managed, which in turn leads to the selection of which services to include.

Consequently, the purpose of the setup, and thereby the initiator, is central to the design of a CLS. Three types of actors that initiated CLSs were identified, and these had different purposes: (1) the municipality had the purpose of reducing environmental impact and disturbances to third parties; (2) the developer had the purpose of facilitating the delivery process to reduce disturbances to activities in the vicinity of the construction site; (3) the main contractor had the purpose of ensuring efficient deliveries to improve on-site productivity. The contractors' purpose follows traditional TPL descriptions, where a buyer outsources logistics activities to a supplier (Hertz and Alfredsson, 2003). In contrast, the municipality and the developer did not have these types of activities. Instead, these actors used the CLS to control the flows to, from and on construction sites. These actors chose to include services to help accomplish this purpose, similar to city logistics setups (Dubois et al., 2019). The purpose of a CLS thus depends on the scope of responsibility that the initiator has, i.e. if the focus is on the program level (e.g. a municipal urban development area), the portfolio level (e.g. a contractor initiated CLS to support multiple projects) or the project level (e.g. a developer refurbishing a hospital) (Martinsuo and Hoverfält, 2018).

The different purposes also relate to the division of construction logistics suggested by Ghanem et al. (2018). Instead of the division into on-site or off-site as Ghanem et al. (2018) suggest, urban areas can be divided into three zones based on the three types of initiators. The first, inner zone is the construction site, the second, middle zone is the area in the vicinity of the construction site and the third, outer, zone is the surrounding city. The zone of interest for the initiator determines which actors will be part of the CLS: just the main contractor and 
IJPDLM 51,4 its subcontractors on site, or suppliers, developers and transporters located off-site. Therefore, we suggest that the purpose of the setup impacts the actors involved (no. 1 in Figure 1). This relation can be explained with the examples of cases C, E and I. These were initiated by the main contractor and did not involve any public administrative bodies like the other cases did (public developer, regional councils, municipal government). The contractor mainly focused on the inner zone (the site) and did not need to involve any public administrative actors to efficiently organize the logistics within this zone. In all cases but $\mathrm{C}$, the CLSs had been jointly designed by the TPL provider and the initiator. Thus, there seemed to be a desire to bring logistics knowledge to the construction industry with the help of the CLS. Hence, the TPL provider not only acted as the systems integrator but also as the systems designer in the CLSs.

The purpose of the setup impacts the level of customization (no. 2 in Figure 1) and time horizon (no. 3 in Figure 1) is the setup to serve one project (fully customized), a program (partly customized) or a main contractor's project portfolio (standardized). The latter is exemplified in the cases $\mathrm{C}$ and $\mathrm{I}$, initiated with the purpose to serve several projects within the main contractors' portfolios. The CLSs must be standardized to keep transaction costs low. Case F also had a standardized setup but on the city level to be used by all projects in that city, i.e., the program level. All three cases also had longer time horizons than the individual projects they served and were not terminated when the projects ended.

The business relationships were dependent on the time horizon (no. 4 in Figure 1), which was dependent on whether the CLS served a program, a portfolio or a single project. Business relationships are dependent on the actors involved (no 5 in Figure 1). Case A showed that the business relationships within a CLS are more complex than what is found in traditional TPL literature, where the relationship is often one-to-one and the TPL provider's capabilities limit what can be done (Marasco, 2008). Because of the many actors involved in a CLS, the initiating actor is not necessarily the customer. The contract for such a CLS only stipulates the end users' commitment to utilize the CLS and serves as a tool for coordinating actors, in contrast to traditional TPL where the contract dictates the operative expectations and dependences (Chakkol et al., 2018).

Joint investment is related to the actors involved and the purpose (no. 6 and 7 in Figure 1). All three cases with joint investments $(\mathrm{F}, \mathrm{G}$ and $\mathrm{H})$ were municipal-driven urban development programs. The municipal developer strove to take greater responsibility for logistics and made joint investments to support the main contractors and TPL providers. However, as Lundesjö (2015) points out, the municipal purpose was to control the movement of goods related to construction off-site, i.e., to reduce disturbances and environmental impact of transports. In that sense, the municipality as initiator must make investments to ensure that the CLS infrastructure is in place.

The type of services also affects the scope of a CLS, i.e., the number of services included (no. 8 in Figure 1). The four cases with the most services included (A, F, B and C) were all terminal-based. A terminal allows adding services such as short-term storage and the transfer of value-adding activities. Type of services affects the location in relation to the project (no. 9 in Figure 1); if the CLS is located close to the construction site, several services related to the third role (streamlining logistics on site) can be added. Based on the observation that the main purpose for developers and municipalities is to reduce disturbances to third parties through the CLSs, we would like to add a sixth role (Vrijhoef and Koskela, 2000; Ekeskär and Rudberg, 2016) from the perspective of city logistics: to coordinate logistics between the construction project and the community in the vicinity of the site.

The level of customization is also related to the location of the off-site asset-based services (no. 10 in Figure 1). A standard CLS used for several projects, as in C, F and I, had located the 
terminal farther from the project (on the outskirts of the city) as this terminal served several projects and needed a location general enough to assimilate forthcoming projects. The other cases had a customized CLS with off-site services located closer to site. The exceptions were $\mathrm{B}, \mathrm{K}$ and $\mathrm{L}$, which were located in densely populated areas with a lack of space adjacent to their sites.

Our analysis suggests that the purpose of the CLS and the type of services affect the performance evaluation (no. 11 and 12 in Figure 1). The rationale for this is that performance should both show that the purpose has been fulfilled and monitor the utilization of services. This allows for evaluating what services are contributing to the purpose of the CLS in terms of being success criteria or service qualifiers (Atkinson, 1999). Surprisingly, a direct relationship between the purpose of setup and the type of services was not found. Table 4 shows that all cases included the service "booking and planning system". Thus, in contrast to traditional TPL setups where a planning system is not mandatory, for CLSs, they are service qualifiers (Atkinson, 1999). We verified the suggestions of Segerstedt and Olofsson (2010) and Ekeskär and Rudberg (2016) that the main aim of a CLS is to act as a systems integrator, i.e. the fifth role (Ekeskär and Rudberg, 2016). This shows that the management perspective drives the design of CLSs and not the structural decisions as in traditional TPL setups.

\section{Conclusions}

As a response to previous studies' findings ( $c f$. Ekeskär and Rudberg, 2016; Sundquist et al., 2018; Janné and Rudberg, 2020), the purpose of this study was to increase understanding of how structural and management dimensions are related in CLSs by describing how CTPL setups are used. This study identified ten structural and managementrelated dimensions with which to classify CLSs (Table 1). Using these dimensions, case samples of 13 CLSs were analyzed to answer the second research question: to identify the characteristics of different setups (Table 3). With the answers to research questions one (the dimensions) and two (the characteristics), a set of theoretical and managerial implications were found.

\section{Theoretical implications}

A theoretical implication is the framework shown in Figure 1, with the dimensions with which a CLS can be described and the identified relations between the dimensions. This framework suggests an order for designing a CLS, where the managerial dimension of the purpose of the setup guides the design of the structural dimensions, in contrast to how a traditional TPL setup design has been explained. The reason for the traditional TPL setup design is that the way logistics is outsourced create the structures, which in turn dictate how to manage the structures. However, the coordination challenge (part of management) in CLSs dictates the structure of the CTPL setup by means of the services to be included. Further research in other industries is needed to expand the discussion of how the context affects the design of TPL setups. When initiated by municipalities or developers, the use of CLSs is not an outsourcing decision and thus challenges the business-to-business relationships of traditional TPL setups (Chakkol et al., 2018). This implies a separation between initiator and user, with the result that business relationships become complex and confusion about the customer arises (Dubois et al., 2019; Janné and Fredriksson, 2019). Further research in construction logistics should focus on explaining how to improve CLS customer satisfaction through greater understanding of what services fulfill the demands and needs of different actors.

This study also highlighted two contemporary phenomena in TPL services. (1) As a CLS acts as a systems integrator (Ekeskär and Rudberg, 2016), a minimum CLS service to include is a planning system. Therefore, all CLSs are at least considered to be value-creating 4PL
Third-party logistics setups in consruction 
IJPDLM 51,4

\section{4}

setups (Saglietto, 2013). In addition to being the systems integrator, the TPL providers in this study also took the role of a systems designer. This is the next level of TPL $-5 \mathrm{PL}$ as discussed by Hosie et al. (2012). Thus, further research on CLSs can increase our understanding of 5PL. (2) The CLS is a driver for service differentiation among TPL providers as it requires construction-specific services (Sundquist et al., 2018). This forces providers to include services that do not traditionally belong to logistics. Kowalkowski et al. (2017) propose that there is a need to simplify the process of designing logistics setups with the help of standardized service modules. However, further research in both TPL and construction logistics is needed to identify suitable modules.

\section{Managerial implications}

Our findings can help the different actors involved agree on the focus of a CLS and thereby what services and performance measures are the most important. Our findings can be further elaborated into a practical guide on the systematic design of CLSs. The structure and identification of possible services (Table 4) and the relationship between dimensions (Figure 1) provide guidance in the process of designing a CLS. The identified services could also help developers and municipalities, as initiators, to specify appropriate requirements on CLS services. The performance evaluation column in Table 3 also provides a foundation for evaluating CLSs.

The studied CLSs were all Swedish. However, this does not limit the generalizability of our findings to other countries as the construction industry is simultaneously global and local (Mckinsey and Company, 2017). The market presence of different construction companies is in most cases local, with a few exceptions (e.g. Skanska, lendlease, Laing O'Rourke). However, logistics management within construction is similar in most developed countries with similar problems regarding productivity and coordination (Fredriksson et al., 2018). Looking at the published construction logistics research, there is a bias toward publications from Sweden, the UK and the Netherlands (Janné, 2018), indicating that these countries may be forerunners and that other regions can learn from the construction logistics initiatives in these countries.

\section{References}

Atkinson, R. (1999), "Project management: cost, time and quality, two best guesses and a phenomenon, its time to accept other success criteria", International Journal of Project Management, Vol. 17 No. 6, pp. 337-342.

Berglund, M., Van Laarhoven, P., Sharman, G. and Wandel, S. (1999), "Third-party logistics: is there a future?”, The International Journal of Logistics Management, Vol. 10 No. 1, pp. 59-70.

Brax, S.A., Bask, A., Hsuan, J. and Voss, C. (2017), "Service modularity and architecture - an overview and research agenda", International Journal of Operations and Production Management, Vol. 37 No. 6, pp. 686-702.

Chakkol, M., Selviaridis, K. and Finne, M. (2018), "The governance of collaboration in complex projects", International Journal of Operations and Production Management, Vol. 38 No. 4, pp. 997-1019.

Cheng, J.C.P., Law, K.H., Bjornsson, H., Jones, A. and Sriram, R. (2010), “A service oriented framework for construction supply chain integration", Automation in Construction, Vol. 19 No. 2, pp. 245-260.

Christopher, M. (2011), Logistics and Supply Chain Management, 4th ed., Prentice Hall - Financial Times, Edinburgh Gate.

Craighead, C.W., Ketchen, D.J. and Cheng, L. (2016), “'Goldilocks' theorizing in supply chain research: balancing scientific and practical utility via middle-range theory", Transportation Journal, Vol. 55 No. 3, pp. 241-257. 
Department for Business Innovation and Skills (2013), Supply Chain Analysis into the Construction Industry - A Report for the Construction Industrial Strategy, Department for Business Innovation and Skills (BIS), London.

Dubois, A. and Gadde, L.-E. (2000), "Supply strategy and network effects - purchasing behaviour in the construction industry", European Journal of Purchasing and Supply Management, Vol. 6 Nos 3-4, pp. 207-215.

Dubois, A. and Gadde, L.E. (2002a), "The construction industry as a loosely coupled system: implications for productivity and innovation", Construction Management and Economics, Vol. 20 No. 7, pp. 621-631.

Dubois, A. and Gadde, L.-E. (2002b), "Systematic combining: an abductive approach to case research", Journal of Business Research, Vol. 55 No. 7, pp. 553-560.

Dubois, A., Hulthén, K. and Sundquist, V. (2019), "Organising logistics and transport activities in construction”, The International Journal of Logistics Management, Vol. 30 No. 2, pp. 620-640.

Ekeskär, A. and Rudberg, M. (2016), "Third-party logistics in construction: the case of a large hospital project", Construction Management and Economics, Vol. 34 No. 3, pp. 174-191.

Fredriksson, A. (2011), "Materials supply and production outsourcing", Doctoral thesis, Chalmers University of Technology, Gothenburg.

Fredriksson, A. and Jonsson, P. (2009), “Assessing consequences of low-cost sourcing in China”, International Journal of Physical Distribution and Logistics Management, Vol. 39 No. 3, pp. 227-249.

Fredriksson, A., Janné, M., Morel, M., Balm, S., Berden, M., Ploos Van Amstel, W., Hulthén, K., Billger, M., Nolz, P., Van Lier, T. and De Radiguès De Chennevière, P. (2018), Smart Construction Logistics, CLOSER, Gothenburg.

Gebauer, H., Paiola, M. and Saccani, N. (2013), "Characterizing service networks for moving from products to solutions", Industrial Marketing Management, Vol. 42 No. 1, pp. 31-46.

Ghanem, M., Hamzeh, F., Seppänen, O. and Zankoul, E. (2018), "A new perspective of construction logistics and production control: an exploratory study", in GonzaLez, V.A. (Ed.), 26th Annual Conference of the International Group for Lean Construction, International Group for Lean Construction, Chennai, pp. 992-1001.

Halldórsson, Á., Hsuan, J. and Kotzab, H. (2015), "Complementary theories to supply chain management revisited - from borrowing theories to theorizing", Supply Chain Management: An International Journal, Vol. 20 No. 6, pp. 574-586.

Halldórsson, Á. and Vural, C.A. (2019), "Servitization and logistics: building a service-based typology", The 26th Annual EurOMA Conference: Operations Cdding Value to Society, Helsinki.

Heaslip, G. and Kovács, G. (2019), "Examination of service triads in humanitarian logistics", The International Journal of Logistics Management, Vol. 30 No. 2, pp. 595-619.

Hertz, S. and Alfredsson, M. (2003), "Strategic development of third party logistics providers", Industrial Marketing Management, Vol. 32 No. 2, pp. 139-149.

Hosie, P., Sundarakani, B., Tan, A.W.K. and Koźlak, A. (2012), "Determinants of fifth party logistics (5PL): service providers for supply chain management", International Journal of Logistics Systems and Management, Vol. 13 No. 3, pp. 287-316.

Jang, H., Russell, J.S. and Yi, J.S. (2003), "A project manager's level of satisfaction in construction logistics", Canadian Journal of Civil Engineering, Vol. 30 No. 6, pp. 1133-1142.

Janné, M. (2018), "Construction logistics solutions in urban areas", Licentiate thesis, Linköping University, Linköping.

Janné, M. and Fredriksson, A. (2019), "Construction logistics governing guidelines in urban development projects", Construction Innovation, Vol. 19 No. 1, pp. 89-109.

Janné, M. and Rudberg, M. (2020), "Effects of employing third-party logistics arrangements in construction projects", Production Planning and Control. doi: 10.1080/09537287.2020.1821925. 
IJPDLM 51,4

\section{6}

Josephson, P.E. and Saukkoriipi, L. (2007), "Waste in construction projects: call for a new approach", The Centre for Management of the Built Environment, Chalmers University of Technology, Gothenburg.

Kluge, S. (2000), "Empirically grounded construction of types and typologies in qualitative social research", Forum: Qualitative Social Research, Vol. 1 No. 1, pp. 1-11.

Kowalkowski, C., Gebauer, H., Kamp, B. and Parry, G. (2017), "Servitization and deservitization: overview, concepts, and definitions”, Industrial Marketing Management, Vol. 60 No. No., pp. 4-10.

Lambert, D.M. and Cooper, M.C. (2000), "Issues in supply chain management", Industrial Marketing Management, Vol. 29 No. 1, pp. 65-83.

Lindén, S. and Josephson, P.E. (2013), "In-housing or out-sourcing on-site materials handling in housing?”, Journal of Engineering, Design and Technology, Vol. 11 No. 1, pp. 90-106.

Lundesjö, G. (2015), "Consolidation centres in construction logistics”, in Lundesjö, G. (Ed.), Supply Chain Management and Logistics in Construction: Delivering Tomorrow's Built Environment, 1st ed., Kogan Page, London, pp. 225-242.

Marasco, A. (2008), "Third-party logistics: a literature review”, International Journal of Production Economics, Vol. 113 No. 1, pp. 127-147.

Martinsuo, M. and Hoverfält, P. (2018), “Change program management: toward a capability for managing value-oriented, integrated multi-project change in its context", International Journal of Project Management, Vol. 36 No. 1, pp. 134-146.

Mckinsey and Company (2017), Reinventing Construction: A Route to Higher Productivity, McKinsey Global Institute, Shanghai.

Robbins, S. (2015), "Effective management of a construction project supply chain", in Lundesjö, G. (Ed.), Supply Chain Management and Logistics in Construction: Delivering Tomorrow's Built Environment, 1st ed., Kogan Page, London, pp. 62-76.

Saglietto, L. (2013), "Towards a classification of fourth party logistics (4PL)", Universal Journal of Industrial and Business Management, Vol. 1 No. 3, pp. 104-116.

Scarsi, R. and Spinelli, R. (2017), "An analysis of strategic groups in the Third-Party Logistics industry", International Journal of Logistics Systems and Management, Vol. 27 No. 4, pp. 466-486.

Scholman, H.S.A. (1997), Uitbesteding Door Hoofdaannemers, Economisch Instituut voor de Bouwnijverheid, Amsterdam.

Segerstedt, A. and Olofsson, T. (2010), "Supply chains in the construction industry", Supply Chain Management: An International Journal, Vol. 15 No. 5, pp. 347-353.

Selviaridis, K. and Norrman, A. (2015), "Performance-based contracting for advanced logistics services: challenges in its adoption, design and management", International Journal of Physical Distribution and Logistics Management, Vol. 45 No. 6, pp. 592-617.

Selviaridis, K. and Spring, M. (2007), "Third party logistics: a literature review and research agenda", The International Journal of Logistics Management, Vol. 18 No. 1, pp. 125-150.

Shaharudin, M.R., Zailani, S. and Ismail, M. (2014), "Third party logistics orchestrator role in reverse logistics and closed-loop supply chains", International Journal of Logistics Systems and Management, Vol. 18 No. 2, pp. 200-215.

Skjøtt-Larsen, T. (2000), "Third party logistics - from an interorganizational point of view", International Journal of Physical Distribution and Logistics Management, Vol. 30 No. 2, pp. 112-127.

Skjøtt-Larsen, T., Halldórsson, Á., Andersson, D., Dreyer, H., Virum, H. and Ojala, L. (2006), "Third party logistics - a Nordic approach”, International Journal of Value Chain Management, Vol. 1 No. 2, pp. 190-204.

Stefansson, G. (2006), "Collaborative logistics management and the role of third-party service providers", International Journal of Physical Distribution and Logistics Management, Vol. 36 No. 2, pp. 76-92. 
Sundquist, V., Gadde, L.E. and Hulthén, K. (2018), "Reorganizing construction logistics for improved performance", Construction Management and Economics, Vol. 36 No. 1, pp. 49-65.

Voordijk, H. (2000), "The changing logistical system of the building materials supply chain", International Journal of Operations and Production Management, Vol. 20 No. 7, pp. 823-841.

Third-party logistics setups in consruction

Vrijhoef, R. and Koskela, L. (2000), "The four roles of supply chain management in construction", European Journal of Purchasing and Supply Management, Vol. 6 Nos 3-4, pp. 169-178.

Yin, R.K. (2014), Case Study Research: Design and Methods, 5th ed., SAGE Publications, Thousand Oaks, California.

Ying, F., Tookey, J. and Seadon, J. (2018), "Measuring the invisible: a key performance indicator for managing construction logistics performance", Benchmarking: An International Journal, Vol. 25 No. 6, pp. 1921-1934.

\section{Corresponding author}

Anna Fredriksson can be contacted at: anna.fredriksson@liu.se 


\section{IJPDLM 51,4}

\section{Appendix Interview guide}

\begin{tabular}{|l|}
\hline Context of the specific project \\
\hline Timeframe \\
\hline Project size \\
\hline Type of construction project \\
\hline Location of construction project \\
\hline Is something unique about the construction logistics because of: \\
- Location of the construction site? \\
- Construction method? \\
- Economic cycle? \\
\hline
\end{tabular}

\section{Key stakeholders}

Who are the stakeholders? What professions do they represent? What roles and responsibilities do different stakeholders have? Who decides about

- Regulations

- Stakeholder criteria

- Resource use

- Coordination of activities

Who decides who is will be responsible for governing and executing logistics in the project?

How do stakeholders interact?

- Principles for information sharing

- How is knowledge exchanged between actors?

What impact do national laws, regulations, and traditions have on stakeholders?

What impact does the developer have on stakeholders and responsibilities?

\section{Key resources}

What common resources (trucks, forklifts, elevators, load carriers, cranes, IT systems, etc.) need to be governed?

How is resource utilization:

- Planned?

- Organized?

Are there constraints regarding use of resources? (e.g. storage space) How do these constraints impact governance?

\section{Key activities}

What key activities need to be governed?

How is the project planned?

How are activities coordinated?

How is ICT used to coordinate activities?

What impact does the surrounding societal conditions have on site activities? (i.e., traffic, noise regulations, traffic zones, etc.)

\section{Material flows}

How much material enters the construction site? Daily, weekly, during the project? 
What types of materials enter the site?

Are different materials managed differently?

From how many suppliers are materials ordered/delivered?

Where are suppliers located? (distance)

Are materials consolidated before arriving at site?

If yes, describe

What requirements are set on delivery time windows?

How much time is there between ordering material and expected delivery? Does this differ depending on material?

How large a share of the project turnover is represented by supplier materials?

\section{Governance}

What type of contract is used, and how is this set up?

How is tendering conducted?

What is the policy for rewards and penalties?

What is the purpose? What is important to achieve? How was the setup developed?

What are the challenges of governance? What makes it difficult?

What was positive/negative with the chosen setup?

How does the chosen setup work in comparison to other setups?

Would alternative CLSs be possible? Why?

How do developers affect the selected CLS?

How do the CLS affect costs and construction efficiency?

What are the challenges with regards to governance?

- Stakeholders

- Resources

- Activities

- Material flows

- In general 